Technical Note

\title{
Electricity generation and biofertilizer on a dairy farm using anaerobic biodigesters
}

\section{Geração de energia elétrica e biofertilizante em granja leiteira utilizando biodigestores anaeróbios}

\section{Fabio Brongar MILECH ${ }^{1 ; 2}$; Ricardo Moreira CABREIRA²; Maria Laura Gomes Silva LUZ; Carlos Alberto Silveira LUZ $^{3}$; Gizele Ingrid GADOTTI*; Mário Conill GOMES ${ }^{3}$}

\begin{abstract}
${ }_{1}^{1}$ Parte do trabalho de conclusão de curso em Engenharia Agrícola dos dois primeiros autores
2 Engenheiros agrícolas; Universidade Federal de Pelotas; fabiomilech@hotmail.com; ricocabreira@gmail.com

${ }^{3}$ Professores Doutores; Universidade Federal de Pelotas; m.lauraluz@gmail.com;carlossluz@gmail.com; mconill@gmail.com

* Autor para correspondência; Professora Doutora; Universidade Federal de Pelotas; Centro de Engenharias; Rua Almirante Barroso 1734 - CEP: 96010-280 - Pelotas - RS - Brasil; gizele.gadotti@ufpel.edu.br
\end{abstract}

Recebido em: 20-05-2013; Aceito em: 25-01-2015

\begin{abstract}
This study aimed at conducting a technical study and verifying the economic feasibility of implementing anaerobic digesters to treat waste from a dairy farm with 2,200 animals, aimed at scaling for power generation and production of biofertilizer, thus providing reduction of the environmental impact on the property and savings in production costs. The farm currently has a demand of energy $50.000 \mathrm{kWh} \mathrm{month}^{-1}$ and comprises 875 ha exclusively for milk production. Calculations were carried out to establish how many digesters would be required, and from the project was established installer with flowchart, mass balance, and graphical design. Revenues were calculated with the use of biogas and biofertilizer to shoot down spending, respectively, electricity and chemical fertilizers. It was performed an economic analysis to verify the feasibility of the project. The planning horizon was 10 years, with four scenarios: 1) scenario 1: to establish the digesters considering an the average of a year production of biogas and biofertilizer; 2) loss of $50 \%$ in biogas production of scenario 1 ; 3) loss of $30 \%$ of the net income (milk production), which will affect the biogas, biofertilizer production, and energy generation; 4 ) loss of $40 \%$ of net income keeping the same conditions of scenario 3 . It is concluded that about 39 tons of waste arising from the dairy property cease to be launched daily in the soil; through the process of anaerobic digestion for the generation of a clean and sustainable energy, bringing revenue to the transformation of biogas into electricity; the residue of the process of digestion gives rise to biofertilizer, reducing production costs, the study proved to be economically viable under the conditions of three scenarios, with a fall of $37 \%$ of net revenue (scenario 4 ), the project was not viable.
\end{abstract}

Additional keywords: agro industrial project; economic viability; renewable energy source; sustainability; waste.

\begin{abstract}
Resumo
Neste trabalho foi realizado um estudo técnico para verificar a viabilidade econômica de implantação de biodigestores anaeróbios para tratar dejetos do gado leiteiro de uma propriedade rural, com 2.200 animais, visando ao dimensionamento para geração de energia e produção de biofertilizante, propiciando redução do impacto ambiental na propriedade e economia nos custos de produção. A granja, atualmente, tem demanda energética de $50.000 \mathrm{kWh}$ mês $^{-1}$ e dispõe de 875 ha exclusivamente para a produção de leite. Foram realizados os cálculos para estabelecer quantos biodigestores seriam necessários e, a partir deste dado foi estabelecido o projeto técnico de instalação, com fluxograma, balanço de massa e graficação. Foram calculadas as receitas com o uso do biogás e do biofertilizante para abater os gastos, respectivamente, com energia elétrica e fertilizantes químicos. Foi realizada análise econômica para verificar a viabilidade do projeto. Os índices econômicos utilizados foram: VPL, TIR, TIRm e payback. O horizonte de planejamento foi de 10 anos, com quatro cenários: 1) cenário 1: simulou-se a implantação dos biodigestores, considerando valores de produção média anual de biogás e biofertilizante; 2) queda de $50 \%$ na produção de biogás em relação ao cenário $1 ; 3$ ) queda de $30 \%$ da receita líquida (produção de leite) que afetará a produção de biogás, de biofertilizante e geração de energia; 4) queda de $40 \%$ da receita líquida e mesmas condições do cenário 3. Conclui-se que cerca de 39 toneladas de dejetos oriundas do gado leiteiro da propriedade deixam de ser lançados diariamente no solo; que pelo processo de biodigestão anaeróbia há geração de energia limpa e
\end{abstract}


sustentável, trazendo receitas com a transformação do biogás em energia elétrica e que o resíduo do processo de biodigestão dá origem ao biofertilizante, reduzindo custos de produção. O estudo se mostrou economicamente viável de acordo com as condições dos três primeiros cenários; com queda de $37 \%$ da receita líquida (cenário 4), o projeto se tornaria inviável.

Palavras-chave adicionais: dejetos; fonte de energia renovável; projeto agroindustrial; sustentabilidade; viabilidade econômica.

\section{Introduction}

Renewable energy sources are likely to take on a significant share in the global energy matrix in the following years, as societal concern on environmental issues is growing. This concern regards especially on the development of developing countries, with a view to the need for an equitable and fair global society. Rises in oil prices and in the political, social and environmental costs of fossil fuels show that the energy and development issue already is, and will remain being the center of numerous interactions and dynamics in the scenario of global international relations, and it is essential to treat this issue related to development and sustainability also in agriculture and livestock, in order to minimize the impacts of production processes (Pinto Junior, 2007; Guerra \& Youssef, 2011).

Cattle manure is often used as fertilizer supply in agriculture. However, research conducted in the country show that the simple sprinkling of this material in pastures allows the continuity of the biological cost of gastrointestinal nematodes, significantly influencing mortality and productive efficiency of animals (Amaral et al., 2004).

As an alternative to reduce the problem of contamination with animal manure in agriculture, there is the alternative to perform anaerobic biodigestion treatments, which take place in the digesters, transforming biomass into biofertilizer, which can be used as a fertilizer, increasing the crop yield as well as generating biogas, which is a renewable energy source (Medeiros \& Lopes, 2006).

There are several types of biodigesters, but generally, all are basically composed of two parts: a container (tank) to house and allow biomass digestion and a gas meter (hood) for storing biogas.

Different biodigesters can be classified according to their supply system: by batch, horizontal continuous, vertical continuous and semicontinuous. They can also be classified according to the model: Indian, Chinese and Canadian (Comastri Filho, 1981; Gaspar, 2003; Portes, 2005; Lima, 2008; Nishimura, 2009).

The anaerobic biodigestion is usually divided into three phases: hydrolysis, acidogenesis and methanogenesis. However, some authors divide it into four phases, adding acetogenesis, which is an intermediate phase between acidogenesis and methanogenesis (Singh, 1996).

In order to have biogas production, manure undergoes a process of anaerobic digestion. The types of bacteria involved in this process are classified into psichrophilic, mesophilic and thermophilic, whose respective optimum range of operation temperature are $20^{\circ} \mathrm{C}$, between 20 and $45^{\circ} \mathrm{C}$ and above $45^{\circ} \mathrm{C}$, respectively. For biogas production, the ideal temperature is of above $40^{\circ} \mathrm{C}$, when the thermophilic bacteria begin to act (Poulsen, 2003).

The time required for the mixture to be digested in the digester is known as Hydraulic Retention Time (HRT), occurring when the biogas production is maximal. The retention time is determined in a continuous process by the ratio between the digester volume and the daily amount of load introduced, i.e., organic matter (Magalhães, 1986).

Biogas is a flammable gas, a product of the digestive action of methanogenic bacteria, composed mainly of carbon dioxide $\left(\mathrm{CO}_{2}\right)$ and methane $\left(\mathrm{CH}_{4}\right)$, though showing traces of nitrogen $\left(\mathrm{N}_{2}\right)$, hydrogen $\left(\mathrm{H}_{2}\right)$ and hydrogen sulphide $\left(\mathrm{H}_{2} \mathrm{~S}\right)$. It is formed through the decomposition of organic matter (biomass) under anaerobic conditions. The methane, the main component of biogas, is a colorless, odorless and highly combustible gas, with a combustion that features a blue flame with sometimes small red spots, it also does not produce soot and its atmospheric pollution index is lower than that of butane, which is found in cooking gas.

The valuation of biogas is directly related to its calorific value, which is, according to Zago (2003), directly related to the amount of methane in the mix, which can reach 5,000-6,000 kcal.m-3, but may be enhanced by $\mathrm{CO}_{2}$ removal, reaching values of $12,000 \mathrm{kcal} \mathrm{m}^{-3}$.

According to Primavesi et al. (2007), methane $\left(\mathrm{CH}_{4}\right)$ is considered 21 times more harmful to the ozone layer than carbon dioxide $\left(\mathrm{CO}_{2}\right)$, which impacts on reducing global warming. This methane can be equated with the Liquefied Petroleum Gas (LPG), with high burning power, which gives it the ability to be used for domestic space heating or power generation.

The biofertilizer is a natural product obtained from anaerobic digestion of organic material, such as cattle manure. This is produced concurrently with biogas. The biofertilizer is an organic fertilizer and improves the physical, chemical and biological soil characteristics, making its performance more effective and performing the role of protecting plants against pests and diseases. On average, it contains 1.5 to $2.0 \%$ nitrogen $(\mathrm{N}) ; 1.0$ to $1.5 \%$ of phosphorus (P) and 0.5 to $1.0 \%$ of potassium $(\mathrm{K})$, and has a $\mathrm{pH}$ of around 7.5 (Silva et al., 2007; Gaspar, 2003). 
To take advantage of these rural property resources, generating income and reducing the environmental impact, well-designed engineering projects are needed, and it is interesting that the economic analysis of these projects contemplate the enforcement of scenarios of the economy, whose main goal is to simulate price fluctuations of both raw materials and finished product. When a feasibility analysis is done, a planning horizon must be assigned, which is hypothetically the liquidation of the enterprise, and indexes are used to measure such viability: NPV (Net Present Value), IRR (Internal Rate of Return on Investment), MIRR (adjusted rate, which takes into account that the present value of each period is not capitalized by the IRR, but by the AMR (Attractiveness Minimum Rate) and the payback, which is the time required for recovering the invested capital, regardless of the value of money over time (Buarque, 1991).

It is possible to evaluate if a project is attractive or not through some economic indicators. For the project evaluation, it is necessary to assess the indicators in various situations that simulate the difficulties normally encountered by companies and the answers that economic indicators provide, facilitating observation and the versatility of the project.

The higher the NPV the more attractive is the investment. It is an indicator used to show how much the profit is currently worth at the end of the planning horizon, taking into account the value of money over time. The investment is an application of scarce funds that generate income over a period of time, in order to maximize the profit of the company.

The payback calculates the time required for recovery of the invested capital, regardless of the value of money over time.

The AMR is the rate used in the financial market, indicating the possibility of the project to be inadvisable, if the IRR is lower than the AMR (Buarque, 1991; Casarotto, 2009).

The case study of this project came from a farm whose milk production started in 2005, with the intention to diversify activities and provide employment to the wives of the property staff, increasing the families' income, making it a new business, focused on the social question.

Currently, the herd has 2,200 animals, which are all tracked. Current production stands this dairy farm as one of the largest milk producers in the country, occupying the ninth position in the Top 100 ranking of MilkPoint in 2010.

Milk production has an average productivity of $22 \mathrm{~L}$.animal $^{-1}$ day $^{-1}$, with 900 cows in production, which totaled 7,000,000 L in the 2009/2010 period. Milking structure has a fully computerized top generation system, which involved funds of approximately $R \$ 1$ million. The location of the milking parlor is strategic and was designed in order to offer maximum comfort to the cows, which need to move just 500 meters from the field to the milking parlor.
The current project provides solar position and adequate aeration for the welfare of animals, which cannot feel heat. The room has capacity for 40 animals per milking, with another room for waiting, capable of supporting three more batches of 40 . Once in milking, the only contact of workers with the cows is given in cleaning the udder and carrying out quality tests. There is no external contact with the milk, which is drawn from the udder by the milking machine and taken from pipes to a tank for cooling. In this reservoir, the temperature is lowered from $38^{\circ} \mathrm{C}$ (temperature which leaves the cow) to $4^{\circ} \mathrm{C}$, which stabilizes the proliferation of bacteria. Under these conditions, the product maintains its characteristics for up to 5 days.

Currently, the farm only does the storage of milk, which goes directly from the tank to the truck, with collections being held daily, aimed to the industrializing company. The goal is to offer a quality product, in volume and regularly.

This study aimed to carry out a technical study and examine the economic feasibility of anaerobic digesters deployment to treat the waste of a dairy farm with 2,200 animals, aiming at sizing the farm for power generation and production of biofertilizers, providing a reduction of the environmental impact on the property and savings in production costs.

\section{Material and methods}

The study was conducted on a dairy farm with 2,200 animals, located in the south of Rio Grande do Sul state, with 1,300 animals in semiconfinement regime.

The farm now has an energy demand of $50,000 \mathrm{kWh}$ month $^{-1}$ and has 875 ha only for milk production, containing pastures and silage crops.

The calculations were carried out to establish how many biodigesters would be necessary and, from milk production data, the technical project of installation was established with flow chart, mass balance and plotting. Equipment was designed and the number of employees needed to be hired and their functions were established. Revenues from the use of biogas and biofertilizer were calculated to bring down spending on electricity and chemical fertilizers, respectively.

From these data, an economic analysis was conducted to verify the feasibility of the project. The economic indicators used were: NPV, IRR, MIRR and payback, according to Buarque (1991) and Casarotto (2009). The planning horizon was of 10 years.

Four scenarios were simulated:

- Scenario 1: the implementation of biodigester was simulated considering the average annual production values of biogas and biofertilizer;

- Scenario 2: a pessimistic profile with losses of $50 \%$ in biogas production was considered. This scenario was developed based on the weather, as one of the major problems in biogas generation is the change 
in temperature. During winter, lower temperatures may interfere in the biogas production. Thus, an unfavorable scenario, without the aid of technology to correct any problems that may occur during the process of anaerobic biodigestion, was estimated;

- Scenario 3: a pessimistic profile with losses of $30 \%$ in the net income (milk production) was considered, what means that biogas and biofertilizer production and energy generation will be affected;

- Scenario 4: This scenario has the same conditions of scenario 3, but with losses of $40 \%$ in the net income.

The biodigestion to be held will use the manure generated in the milking parlor, waiting room and yoke, with the latter still being built, as it is currently in open air.

\section{Results and discussions}

Calculations were performed on the amount of manure available on the property to feed the anaerobic biodisgestors of Canadian type. Considering that the 1,300 animals produce on average of $30 \mathrm{~kg}$ of manure.animal ${ }^{-1}$.day ${ }^{-1}$, and that $2.5 \mathrm{~L} \mathrm{H}_{2} \mathrm{O}^{.} \mathrm{kg}^{-1}$ are used for cleaning the waste, the value of $136.5 \mathrm{~m}^{3}$.day ${ }^{-1}$ of material was reached. However, considering that the solid part of the manure will be removed $(5,800 \mathrm{~kg}$ of solid manure.day ${ }^{-1}$, divided by its density of $\mathrm{kg} \cdot \mathrm{m}^{-3}$ ), $126.83 \mathrm{~m}^{3}$. day ${ }^{-1} \mathrm{go}$ into the biodigesters. Then 2 digesters were specified for $63.42 \mathrm{~m}^{3}$.day ${ }^{-1}$ each (Figure 1).

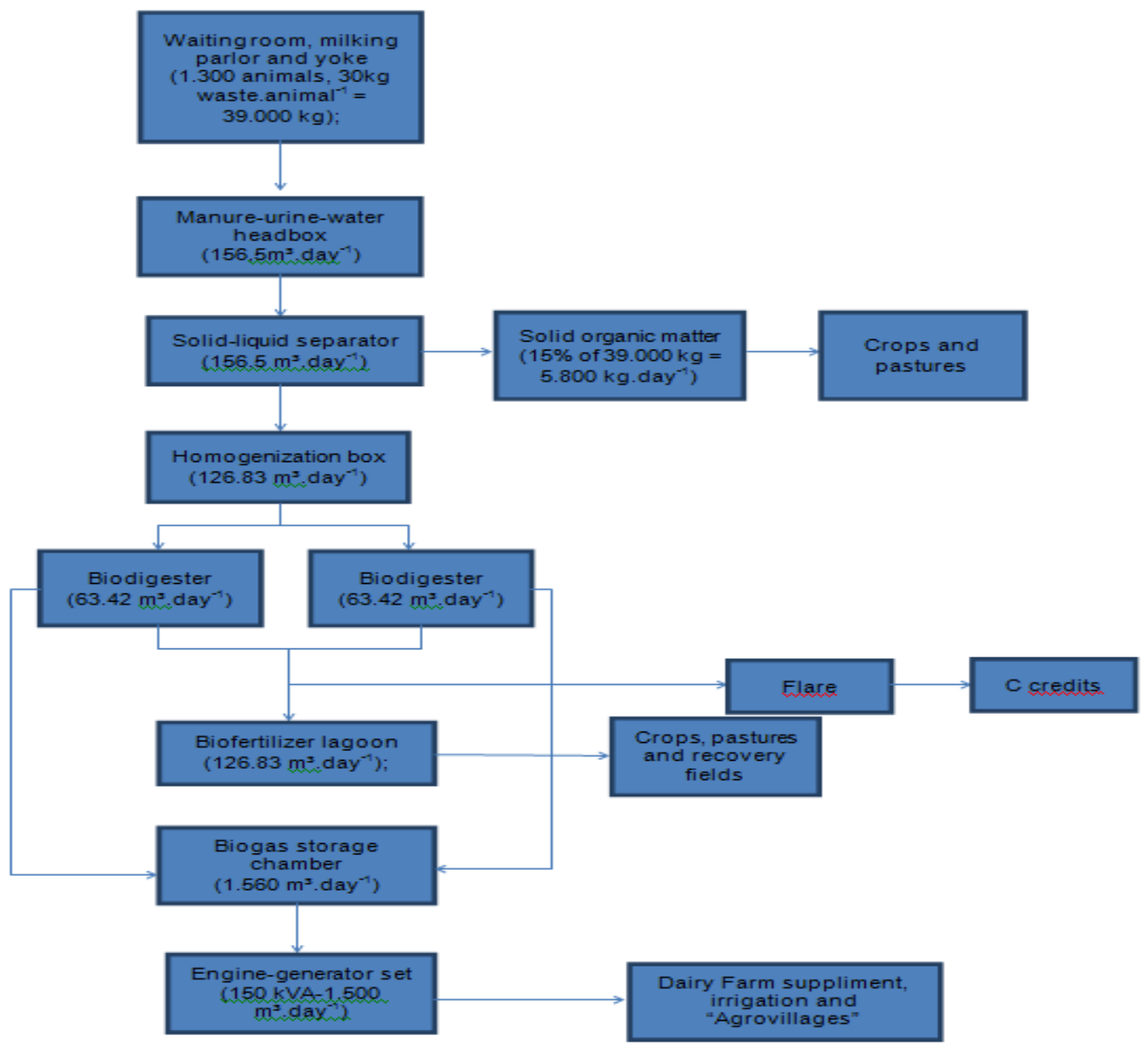

Figure 1 - Anaerobic biodigestion process flowchart of the case study.

The manure generated by the 1,300 animals were of around 39 t.day $^{-1}$, considering the waiting room, the milking parlor and the yoke (Figure 2), which will be scraped through two mechanical scrapers (1 hp) and washed with high-pressure hoses, directing the water with the waste to a PVC pipe calculated with a $250 \mathrm{~mm}$ diameter. This wash water goes to the manure headbox through gravity, and it is $42 \mathrm{~m}$ distant from the waiting room and the milking parlor and $175 \mathrm{~m}$ from the yoke. This box (Figure 3a), with dimensions of $5 \times 6 \times 1.20 \mathrm{~m}$ and a volume of $36 \mathrm{~m}^{3}$ receives $136.5 \mathrm{~m}^{3}$ of manure.day ${ }^{-1}$. When the manure leaves the box, the manure will go to a solids separator (Figure 3a), driven by an $5 \mathrm{hp}$ electric engine, being able to separate $480 \mathrm{~m}^{3}$.day ${ }^{-1}$ of manure. The solids part (fiber) will go to a reservoir and can be used directly in the soil as a fertilizer, and the liquid will go to a homogenization box (Figure 3b). The separation prevents a large amount of solids from going into the biodigester, thus minimizing maintenance and internal cleaning costs. 


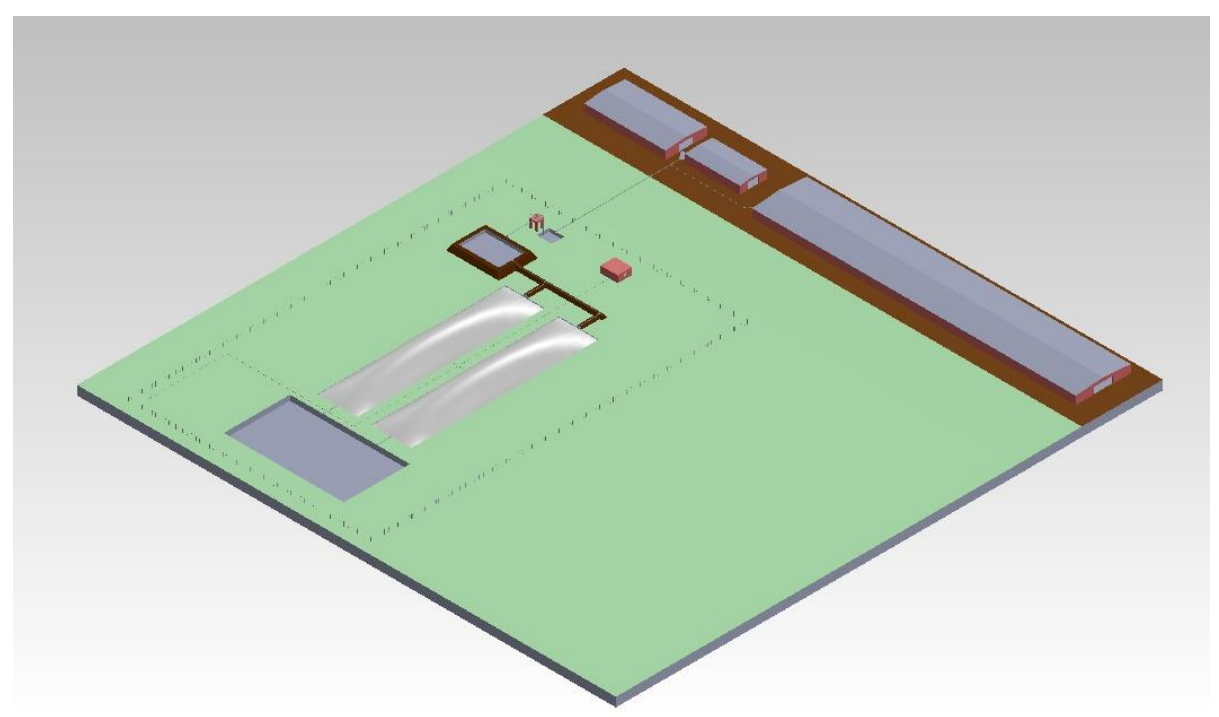

Figure 2 - Isometric projection of the digestors place of establishment.

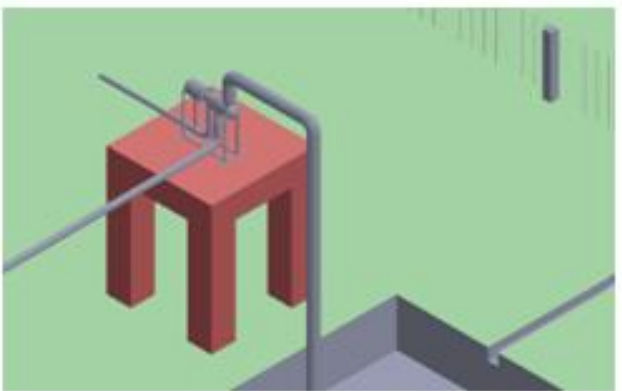

(a)

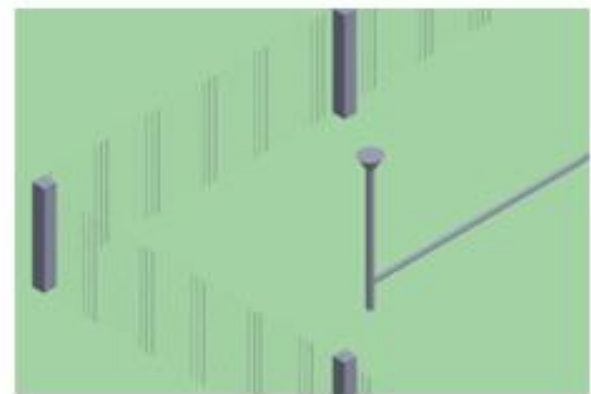

(c)

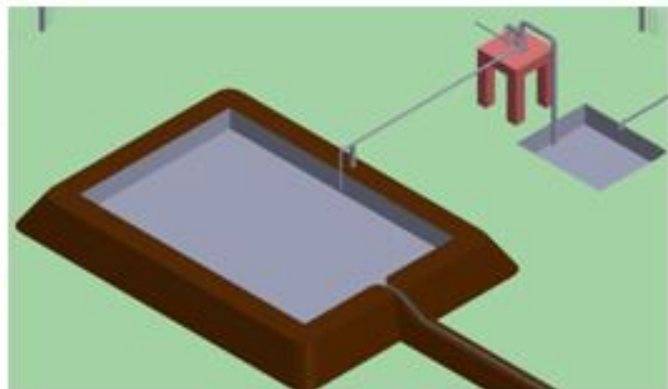

(b)

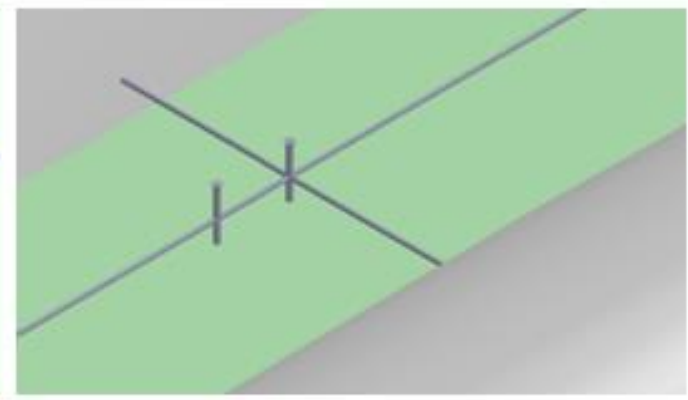

(d)

Figure 3 - Details in isometric projection of the digestors place of establishment: a) solid-liquid separator; b) homogenization box; c) flare; d) gas control valves between biodigesters.

The homogenization box will have a dimension of $15 \times 10 \times 2 \mathrm{~m}$, having a total volume of $300 \mathrm{~m}^{3}$, receiving $126.83 \mathrm{~m}^{3}$ day $^{-1}$ of liquid manure from the solids separator, with the purpose of regulating the manure inlet flow in the biodigesters, maintaining the flow uniform and continuous.

A flare (Figure $3 \mathrm{c}$ ) and gas control valves of biodigesters (Figure $3 d$ ) were also projected.

The biodigesters chambers will be dug into the soil at $2.20 \mathrm{~m}$ deep, which has as typical characteristics of the region soil as transported with 2:1 clay mineral, having low permeability and grayish color. Although the soil has low permeability, it will be coated with a PVC geomembrane with additives, in black, isolating soil waste.

Over the chambers, it will also be placed one PVC geomembrane with additives, in white. These chambers will act as produced biogas reservoirs, capable of storing $1,788.29 \mathrm{~m}^{3}$ each, with the total volume of each biodigester being of $2,310 \mathrm{~m}^{3}$. The hydraulic retention time (HRT) will be of 35 days. 
Within each digester will be an electric handler, responsible for the movement of manure.

The biodigesters will have a biofertilizer output of $1,407.9 \mathrm{~kg}$ day ${ }^{-1}$, with $647.4 \mathrm{~kg} \mathrm{day}^{-1}$ of $\mathrm{N}$, $390 \mathrm{~kg} \mathrm{day}^{-1}$ of $\mathrm{P}$ and $370 \mathrm{~kg} \mathrm{day}^{-1}$ of $\mathrm{K}$, falling directly into the biofertilizer lagoon, which has a total volume of $2,250 \mathrm{~m}^{3}$.

The biogas production, considering the two biodigesters, is of $1,560 \mathrm{~m}^{3}$ day $^{-1}$, which are channeled to an Otto engine-generator cycle set of 150 kVA, with 6 cylinders in line, radiator, intercooler, intake manifold, air filters, air/gas mix controller, coils, gas shut-off valves, gas solenoid valve, pressure regulator, gas controller, air/gas mixer and turbine, with a capacity of $1,500 \mathrm{~m}^{3}$ day $^{-1}$.

Considering that $1 \mathrm{~kg}$ of manure yields $0.04 \mathrm{~m}^{3}$ of biogas (Barros, 2011), a production of $1,560 \mathrm{~m}^{3}$ of biogas day ${ }^{-1}$ is reached; and $0.62 \mathrm{~m}^{3}$ of biogas generates $1 \mathrm{kWh}$. Thus, an electricity production of 2,516.13 $\mathrm{kWh}^{-1 a y}$ is obtained. Considering the amount of $\mathrm{kWh}$ at $\mathrm{R} \$ 0.15$, a daily income of approximately $\mathrm{R} \$ 377.42$ is obtained, totalling $\mathrm{R} \$ 137,758.11 \mathrm{yr}^{-1}$. The property currently requires 50,000 $\mathrm{kWh} \mathrm{month}^{-1}$, and biogas can provide $75,480 \mathrm{kWh} \mathrm{month}^{-1}$, so the excess energy of 25,480 kWh month-1 can be sold.

As for the biodigesters by-product, about $1,407.9 \mathrm{~kg} \mathrm{day}^{-1}$ of biofertilizer can be generated. The 39,000 of manure day ${ }^{-1}$, with $1.66 \%$ Nitrogen (N) will yield $647.4 \mathrm{~kg}$ day $^{-1}$ of $\mathrm{N}$; with $1.00 \%$ Phosphorus $(\mathrm{P})$ will yield $390 \mathrm{~kg}^{-1}$ day $^{-1}$ of $\mathrm{P}$ and with $0.95 \%$ Potassium $(\mathrm{K})$ will yield $370.5 \mathrm{~kg}$ day $^{1}$ of $\mathrm{K}$, which added to the pasture soil may increase milk productivity.

Table 1 shows the items required for the implementation of the project, with their costs and depletion values.

Table 1 - Project necessary investment and respective depletions.

\begin{tabular}{|c|c|c|c|c|c|}
\hline \multirow{2}{*}{ Item } & \multirow{2}{*}{ Unit } & \multirow{2}{*}{ Quantity } & \multicolumn{2}{|c|}{ Investments } & \multirow{2}{*}{ Depletion $(\mathrm{R} \$)$} \\
\hline & & & Unit cost $(R \$)$ & Total cost $(R \$)$ & \\
\hline Headbox & $\mathrm{m}^{2}$ & 30 & - & $2,784.43$ & 111.38 \\
\hline Homogenization box & $\mathrm{m}^{2}$ & 150 & - & $3,193.73$ & 127.75 \\
\hline Biodigester 1 & $\mathrm{~m}^{2}$ & 750 & - & $226,601.83$ & $9,064.07$ \\
\hline Biodigester 2 & $\mathrm{~m}^{2}$ & 750 & - & $226,601.83$ & $9,064.07$ \\
\hline Biofertilizer box & $\mathrm{m}^{2}$ & 800 & - & $5,339.73$ & 213.59 \\
\hline Yoke & $\mathrm{m}^{2}$ & 1,000 & - & $165,998.40$ & $6,639.94$ \\
\hline Scraper & unit & 2 & $3,000.00$ & $6,000.00$ & 600.00 \\
\hline Liquid manure distributor & unit & 1 & $22,000.00$ & $22,000.00$ & $2,200.00$ \\
\hline Collection engine pump & unit & 1 & 700.00 & 700.00 & 70.00 \\
\hline Solids separator & unit & 1 & $21,000.00$ & $21,000.00$ & $2,100.00$ \\
\hline Engine-generator & unit & 1 & $140,000.00$ & $140,000.00$ & $14,000.00$ \\
\hline Handler & unit & 2 & $13,000.00$ & $26,000.00$ & $2,600.00$ \\
\hline Flare & unit & 2 & 60.00 & 120.00 & 12.00 \\
\hline Valve system & unit & 2 & 30.00 & 60.00 & 6.00 \\
\hline Manometer & unit & 2 & 80.00 & 160.00 & 16.00 \\
\hline Sub-Total & & & & $846,559.93$ & $46,824.80$ \\
\hline Project & & & & $8,465.60$ & \\
\hline Licenses & & & & $8,465.60$ & \\
\hline Equipment assembling & & & & $136,914.00$ & \\
\hline Empowerment & & & & $1,500.00$ & \\
\hline Unexpected & & & & $16,931.20$ & \\
\hline Total & & & & $1,018,836.33$ & \\
\hline
\end{tabular}

Budgeting of all items necessary for the implementation of the project was carried out and through Table 1 it can be seen that the value of the total investment was of approximately $R \$$ $1,000,000.00$. The depletion values of each item and its quantities can also be seen.

Taking into account that the farm already has staff available to carry out the cleaning of manure generated by the animals, only three more employees would be hired to assist in this task: a technician in Environmental Management, which would have as main functions to control the maintenance and operation of biodigester equipment, and two other employees, for general services.
To establish the annual variable costs, it was necessary to calculate fuel consumption ( $R \$ 120,960.00)$, the power consumption of the equipment necessary for the operation of the biogas and biofertilizer generation process ( $R \$ 20,975.78)$, water consumption ( $R \$ 5,400.00)$, expenditures on direct labor ( $R \$ 47,759.18)$ and a percentage of $2 \%$ of the total value of these costs.

The company responsible for the biodigesters installation will provide a training course for managers and for the farm technician.

In parallel to the fixed costs, the annual variable costs were calculated, containing the maintenance $(R \$ 50,941.82)$, insurance $(R \$ 5,094.18)$ and 
$2 \%$ on those values.

It was considered that the project does not have variable expenses (expenses that ensure income generation) because the final product generated is not sold to third parties, but used only for the demand of the own farm.

For the calculation of annual fixed costs, administrative expenses such as telephone, computer and office supplies ( $R \$ 1,080.00)$ were considered, plus $1 \%$ for others.

Annual revenues were exposed in two ways: production of urea, superphosphate and potassium chloride, which are resulting from the anaerobic biodigestion process ( $R \$ 475,721.11)$, and biogas production turned into electricity $(\mathrm{R} \$ 137,758.06)$.

For the realization of the project, a funding of $70 \%$ of total investments would be necessary, which would be held in a financial institution, and the owners of the farm would take the remaining $30 \%$ from their own resources.

The financial institution that would finance the project has a program for reducing emissions of greenhouse gases in agriculture, the ABC program, whose purpose is the establishment, improvement and maintenance of waste treatment systems and the use of manure from animal production in power generation and composting (ABC: Treatment of waste). Funding would be of 10 years, with $5 \%$ interest per year, a year of grace and "Price" amortization system.

Table 2 describes the NPV values, IRR, MIRR and payback values for each simulated scenario.

Table 2 - Economic indexes considering simulated scenarios.

\begin{tabular}{lrrrr}
\hline Indicators $^{*}$ & Scenario 1 & Scenario 2 & Scenario 3 & Scenario 4 \\
\hline AMR (\%) & 5.28 & 5.28 & 5.28 & 5.28 \\
Investment (R\$) & $462,356.13$ & $462,356.13$ & $462,356.13$ & $462,356.13$ \\
NPV (R\$) & $1,489,042.79$ & $964,335.63$ & $87,033.04$ & $-240,102.57$ \\
IRR (\%) & 54.70 & 39.00 & 9.02 & - \\
MIRR (\%) & 21.59 & 17.84 & 7.11 & - \\
Payback (years) & 2 & 3 & 7 & - \\
\hline
\end{tabular}

$\left(^{\star}\right)$ AMR = Attractiveness Minimum Rate; NPV = Net Present Value; IRR = Internal Rate of Return on Investment ; MIRR = Modified Internal Rate of Return on Investment.

Analyzing the data in Table 2, the scenarios 1,2 and 3 are attractive, because the MIRR is larger than the considered AMR, and the scenario 4 was not attractive, showing no capital return, in a 10 years planning horizon.

It can also be observed that with the values of scenarios 1 and 2, the project features a return on invested capital (payback) considerably lower compared to scenario 3 .

\section{Conclusions}

It can be concluded with this work that:

- About 39 tons of manure coming from the study property cattle cease to be launched daily in the soil, minimizing the chances of contamination of the water table and considerably reducing the emission of harmful gases to the ozone layer $\left(\mathrm{O}_{3}\right)$, resulting in reduced environmental impact;

- Through the anaerobic biodigestion process there is generation of a clean and sustainable energy, bringing income with the transformation of biogas into electricity, reducing the environmental impact;

- The biodigestion process residue gives rise to the biofertilizer, which is an input for the property, reducing production costs;

- The process gives the producer treatment and recovery of waste, making it a source of income;

- The study was economically feasible in accordance with the conditions of the scenarios 1,2 and 3 , where even simulating pessimistic projections, such as scenarios 2, 3 and 4, only when there is a drop of
$37 \%$ of net revenue, as shown in the scenario 4 , the project was not viable.

\section{References}

Amaral CC, Amaral LA, Júnior JL, Nascimento AA, Ferreira DS, Machado MRF (2004) Biodigestão anaeróbia de dejetos de bovinos leiteiros submetidos a diferentes tempos de retenção hidráulica. Revista Ciência Rural 34(6):1897-1902.

Barros TD (2011) Biogás. In: Jardine JG, Barros TD, Manzoni LP (ed) Arvore do Conhecimento: Agroenergia. Embrapa. Available at: <http://www.agencia.cnptia.embrapa.br/gestor/agroen ergia/arvore/CONT000fj1fm1ev02wyiv802hvm3jlsm2 z9b.html. (accessed: nov. 19 2014)

Buarque C (1991) Avaliação econômica de projetos: uma apresentação didática. Campus. 266p.

Casarroto F N (2009) Elaboração de projetos empresariais: análise estratégica, estudo de viabilidade e plano de negócio. São Paulo: Atlas. 236p.

Comastri Filho JA (1981) Biogás: Independência energética do pantanal mato-grossense. EMBRAPA UEPAE de Corumbá-MS. Circular Técnica n.9. 53p.

Gaspar RMBL (2003) Utilização de biodigestor em pequenas e médias propriedades rurais com ênfase na agregação de valor: um estudo de caso na região de Toledo-PR. Universidade Federal de Santa Catarina (Dissertation of Master Degree in Production Engineering). 106p. 
Guerra JBSOA, Youssef YA (Org.) (2011) As energias renováveis no Brasil: entre o mercado e a universidade. Unisul. 232p.

Lima HQ (2008) Sustentabilidade energética e ambiental do sítio ecológico Falkoski. Engenharia em energia e desenvolvimento sustentável. Available at:< http://sitioecologicofalkoski.com/paginas/falkoski.pdf>. (accessed: dez. 09 2012).

Magalhães APT (1986) Biogás: um projeto de saneamento urbano. Nobel. 120p.

Medeiros MB, Lopes, JB (2006) Biofertilizantes líquidos e sustentabilidade agrícola. Available in:<http://www.seagri.ba.gob.br/pdf/comunicação05_v7 n.3.pdf> (accessed: dec. 08 2012)

Nishimura R (2009) Análise de balanço energético de sistema de produção de biogás em granja de suínos: implementação de aplicativo computacional. Universidade Federal de Mato Grosso do Sul (Dissertation of Master Degree in Electrical Engineering). 84p.

Pinto Junior H (2007) Economia da energia: fundamentos econômicos, evolução histórica e organização industrial. Elsevier. 360p.
Portes ZA, Florentino HO (2005) Aplicativo computacional para projetos e construções de biodigestores rurais. Energia na Agricultura 21: 118-138.

Poulsen TG. (2003) Solid waste management.

Available

at:

<http://www.bio.aau.dk/dowload/MT_Ansatte/Tjalfe/soli d_waste/intwastech5.pdf> (accessed dec. 09 2012).

Primavesi O, Arzabe C, Pedreira MS (2007) Aquecimento global e mudanças climáticas: uma visão integrada tropical. Embrapa Pecuária Sudeste 140p.

Silva, AF, Pinto JM, França CRRS, Fernandes SC, Gomes TCA, Silva, MSL, Matos, ANB (2007) Preparo e uso de biofertilizantes líquidos. Comunicado Técnico 130 - Embrapa Semi-Árido. 4p.

Singh SK (1996) Effect of cupric nitrate on acceleration of biogas production. Energy Conversion and Management 37(4):417-419.

Zago S (2003) Potencialidade da produção de energia através do biogás integrada à melhoria ambiental em propriedades rurais com criação intensiva de animais, na região do meio-oeste catarinense (Dissertation of Master Degree in Enviromental Engineering). FURB. 103p. 